\title{
A epidemia de varíola e o medo da vacina em Goiás
}

\section{The smallpox epidemic and fear of the vaccine in Goiás}

\author{
Eliézer Cardoso de Oliveira \\ Professor e coordenador do Mestrado em Território e Expressões \\ Culturais no Cerrado/Universidade Estadual de Goiás. \\ Unidade Universitária de Ciências Socioeconômicas \\ e Humanas de Anápolis. \\ Avenida Juscelino Kubitschek, 146 \\ 75110-390 - Anápolis - GO - Brasil \\ tecer@ueg.com.br
}

OLIVEIRA, Eliézer Cardoso de. A epidemia de varíola e o medo da vacina em Goiás. História, Ciências, Saúde - Manguinhos, Rio de Janeiro, v.20, n.3, jul.-set. 2003, p.939-962.

\section{Resumo}

Analisa dois aspectos referentes à varíola em Goiás. Um se refere à reconstituição histórica dos principais surtos no estado, nos séculos XIX e nas três primeiras décadas do XX, focalizando o aumento dos surtos epidêmicos da doença como consequência da modernização dos meios de transportes e do crescimento demográfico. O outro centra-se na resistência da população goiana do século XIX à vacina antivariólica, que pode ser compreendida num quadro mais amplo de resistência às medidas civilizadoras implantadas pelo Estado em Goiás. Em termos metodológicos, o artigo considera a varíola evento hermenêutico, procurando situá-la na proposta de normatização higiênica pretendida pelos administradores públicos, então em choque com os valores e atitudes da população local.

Palavras-chave: Goiás; epidemia; varíola; vacina; processo civilizador.

\section{Abstract}

An analysis is made of two aspects of smallpox in the Brazilian state of Goiás. One is a historical reconstruction of the main outbreaks in the state in the nineteenth century and the first three decades of the twentieth century, focusing on the increased number of epidemics of the disease as transportation was modernized and the population grew. The other concerns the people's resistance in the nineteenth century to the smallpox vaccine, which may be understood in a broader context of resistance to the modernizations introduced by the State in Goiás. According to the methodology used, smallpox is regarded as a hermeneutic event within the broader efforts to standardize public health made by the public authorities, which ran counter to the local people's values and attitudes.

Keywords: Goiás; epidemic; smallpox; vaccine; civilization process. 
$\mathrm{D}$ oença milenar, conhecida no Egito e China antigos, e transmitida pelo vírus Poxvirus variolae, a varíola é contagiosa e desconfortável em seus três tipos: o hemorrágico, raro e grave, caracterizado por hemorragia cutânea e possibilidade de óbito em até quatro dias; o major, forma clássica da doença, caracterizada geralmente por febre alta, calafrios, dor intensa nos membros e no estômago, vômitos, suor, delírio, olhos lacrimejantes, forte dor de cabeça, inchaço no rosto, acarretando a morte em 30\% dos atingidos; o minor, também conhecido por alastrim, com pouca erupção e letalidade inferior a 1\% (Gazêta, 2006, p.27). Nos relatos anteriores ao século XX, eram predominantemente associadas à varíola as descrições referentes a sua forma grave (major), também conhecida popularmente como bexiga e temida por sua letalidade e pelas visíveis cicatrizes que podia deixar no corpo dos sobreviventes.

Exemplo paradigmático do poder da ciência moderna em controlar a natureza, a varíola foi a primeira doença epidêmica a ser erradicada por meio de projeto deliberado de vacinação mundial, concluído na década de 1970. ${ }^{1}$ A descoberta da vacina se deu em 1796, pelo médico inglês Edward Jenner, ao constatar que as pessoas inoculadas com a chamada varíola bovina (cow-pox) não contraíam mais a varíola. Daí "a inoculação com cow-pox, em vez da varíola comum, ficou conhecida como vacinação, da palavra latina vaccinus, que significa 'de uma vacca, ('vaca')' (Farrell, 2003, p.52). A partir de então, os humanos teriam alternativa relativamente eficiente para combater uma doença socialmente temida. A relatividade do método derivava do fato de que a aplicação da vacina

causava erupções brandas, semelhantes às da varíola, mas protegia contra a doença humana. Das pústulas surgidas nas pessoas vacinadas era novamente retirado o produto que servia para novas inoculações. Esta prática profilática tinha como inconveniente o fato de seu efeito diminuir com o tempo. Além disso, a reinoculação constante da vacina em seres humanos causava a transmissão de diversas outras doenças como a sífilis e a tuberculose (Teixeira, Almeida, 2003, p.477).

Ainda assim, a descoberta de Jenner espalhou-se gradativamente pelo mundo, devendo ter chegado no Brasil no início do século XIX²; em 1811 foi criada a Junta Vacínica da Corte, responsável por sua aplicação no Rio de Janeiro. Em 1846 criou-se o Instituto Vacínico do Império, responsável por promover a vacinação nas diferentes províncias. Em 1886 esse órgão foi extinto, e a vacinação ficou sob o encargo da recém-criada Inspetoria Geral de Higiene; com isso, a "já precária vacinação na Corte" foi "praticamente desativada e a das províncias deixadas a sua própria sorte" (Teixeira, Almeida, 2003, p.479). A situação atenuou-se em 1894, quando o barão de Pedro Affonso criou o Instituto Vacínico Municipal, instituição particular subsidiada pelo poder público, que passou a produzir a vacina animal em solo brasileiro e foi a principal referência na produção de vacina no Brasil até ser incorporado pelo Instituto Oswaldo Cruz em 1921 (Fernandes, 1999, p.83). Desde então esse instituto ficou responsável por produzir a vacina antivariólica até 1972, quando praticamente a varíola já estava extinta no país.

O objetivo central deste artigo é analisar os surtos epidêmicos e a vacinação antivariólica em Goiás, no século XIX e nas três primeiras décadas do XX. Em texto pioneiro, publicado em 1972, os historiadores franceses dos Annales, Jacques Revel e Jean-Pierre Peter (1976), chamaram a atenção para as duas perspectivas extremas que os historiadores das doenças deveriam evitar: a primeira, chamada de história natural da morbidade, enfatiza mais a 
doença do que o homem, considerado mero hospedeiro do agente causador da doença; a segunda, chamada de sociologia da morbidade, enfatiza mais os impactos sociais e culturais do que a doença em si, considerada quase pretexto para análise de fatos demográficos, econômicos, institucionais, religiosos e administrativos. De acordo com esses autores, a solução para o dilema metodológico está numa análise ponderada que evite radicalismos biologicistas e historicistas, reconhecendo que o objeto da história das doenças não é nem só a 'doença', nem só o 'homem', mas o 'homem doente' (p.144).

Embora reconheça a pertinência dessa orientação de procurar manter postura equilibrada, este artigo, inevitavelmente, privilegia os aspectos culturais da doença em relação aos biológicos. Nesse sentido, sua contribuição para a história das doenças no Brasil está em mostrar as peculiaridades da epidemia e da vacinação no contexto físico e sociocultural de Goiás do século XIX e parte do XX. As atitudes e as representações em relação à varíola e à vacinação tiveram suas especificidades regionais e, portanto, sua compreensão históricocultural requer inseri-las no que Clifford Geertz (1997) denominou estruturas locais de saber.

Isso implica uma postura metodológica hermenêutica. A hermenêutica clássica, religiosa ou jurídica, parte do pressuposto de que a compreensão de um texto exige situá-lo no contexto cultural em que foi produzido. Atualmente, graças principalmente às contribuições de HansGeorge Gadamer (1997), a hermenêutica ampliou sua abrangência, não se restringindo meramente a textos antigos; assim, é utilizada por antropólogos e historiadores culturais para análise de rituais e práticas culturais, inserindo-os na "teia de significados simbólicos" que os envolve (Geertz, 1997, p.4).

Nesse sentido, considerou-se a varíola um evento hermenêutico. O círculo hermenêutico pressupõe um jogo entre o particular e o geral: o estudo do geral ajuda a compreender melhor o particular, e vice-versa. Isso significa que a compreensão da especificidade da varíola e da vacinação requer a análise do contexto histórico-cultural da sociedade goiana, da mesma forma que sua análise propicia melhor compreensão daquela sociedade. Em suma, ao considerar a varíola um evento hermenêutico, procura-se situá-la em um contexto cultural específico, reconhecendo seus efeitos na história e considerando-a heuristicamente inspiradora de ações e representações simbólicas.

A categoria que demonstra a especificidade de Goiás em relação à varíola é 'civilização', utilizada no sentido dado por Norbert Elias (1994) ao processo civilizador: pacificação da sociedade e controle dos instintos. A criação do Estado absolutista domesticou o instinto guerreiro da nobreza militar, que adotou gradativamente regras de etiquetas inibidoras de determinados atos e funções corporais (comer com as mãos, urinar, defecar, escarrar etc.) em público. Esse comportamento 'civilizado' da nobreza foi adotado pela burguesia e passou a ser sinal distintivo da superioridade europeia sobre os outros povos.

Em Goiás, desde o início da colonização, o termo civilização foi utilizado como principal característica que distinguia os colonizadores dos indígenas, dos escravos africanos e dos mestiços. No entanto, as qualidades imputadas ao 'homem civilizado' variavam com o tempo. No século XVIII, ser civilizado significava a rejeição do assassinato sem motivo, do canibalismo e do incesto, e o respeito à propriedade, à Coroa e ao catolicismo No século XIX, passou a significar também aprimoramento intelectual pela educação, polidez, civismo, utilização de preceitos higienistas para regular a vida privada e comunitária. De acordo com Jurandir 
Freire Costa (1979, p.120), no século XIX, "não bastava ser branco, católico ou proprietário de terras", sendo preciso adotar uma "nova etiqueta", "um novo código de relacionamento social" e "novas formas de sociabilidade".

Em Goiás, a implantação do projeto civilizador foi mais complicada do que nos demais lugares. Região de difícil acesso, encravada no centro do país, só foi colonizada pelos portugueses devido à descoberta de ricas jazidas de ouro, no início do século XVIII. O XIX, no entanto, foi de decadência da produção aurífera, de ruralização acentuada, de exílio de brancos para outras províncias, de fraqueza da atividade produtiva e comercial. A elite branca e católica misturou-se aos negros e mestiços, absorvendo muitas práticas que iam de encontro às admitidas como civilizadas.

Essa especificidade da civilização goiana, objeto de ácidas críticas dos observadores estrangeiros, foi internalizada pela elite administrativa como deficiência. Daí a desconfiança e a ojeriza dos capitães-gerais, dos presidentes de província e presidentes de estado em relação às práticas culturais indígenas, africanas e sertanejas. Daí também o desejo de implantar práticas civilizadoras em oposição aos costumes populares.

Nesse sentido, os surtos epidêmicos e a vacinação contra a varíola possuem valor hermenêutico, pois elucidam as clivagens entre os comportamentos e valores da elite 'civilizada' em relação aos da cultura popular e a especificidade físico-cultural de Goiás em relação aos demais espaços brasileiros. O isolamento geográfico, a precariedade dos meios de transportes, a debilidade dos núcleos urbanos, o baixo crescimento demográfico eram características que, no século XIX, afastavam Goiás da civilização e, por isso, motivo de frustração por parte da elite administrativa. Esse suposto atraso, no entanto, vai ser fator relevante pela quase ausência de surtos epidêmicos de varíola em Goiás durante todo o século XIX. Por outro lado, no século XX, com a modernização dos meios de transportes e com o aumento demográfico acarretado pela imigração, ocorrerá substancial aumento de casos de varíola em várias localidades goianas.

No século XIX, mesmo sem a ocorrência de grandes surtos epidêmicos, houve considerável esforço dos responsáveis pela administração da província para imunizar a população por meio da vacinação antivariólica - Goiás era uma das mais atrasadas províncias do Império, e a vacinação, um meio de mostrar sua inserção no processo civilizador. Essa campanha pública de vacinação colidia, porém, com os valores da população goiana, que temia sua eficácia e seu propósito.

Assim, utilizando uma gama de documentos de diversos tipos (relatórios, ofícios, poema, memórias), procurar-se-á mostrar a especificidade regional, em termos de ações e valores, da elite administrativa e do povo em geral em relação à varíola e seu combate por meio da vacinação ${ }^{3}$.

\section{Os surtos epidêmicos de varíola em Goiás}

A imunidade dos sobreviventes à varíola e o fato de seu único hospedeiro ser o homem tornam-na uma doença mais propícia a se propagar em lugares com alta concentração demográfica. Em comunidades de baixa concentração demográfica e com poucos deslocamentos populacionais, era difícil a contaminação desenfreada pelo vírus da varíola. 
Em Goiás dos séculos XVIII e XIX, portanto, com baixas densidade e mobilidade demográficas e com núcleos urbanos reduzidos e afastados uns dos outros, o vírus da varíola raramente conseguia atingir a população. ${ }^{4}$ Isso porque, para o surgimento de novos surtos, era necessário que fosse reintroduzido o vírus do exterior, e as chances de isso acontecer eram remotas, pois o tempo para se chegar a Goiás ultrapassava em muito o do ciclo de transmissibilidade da doença, que durava duas ou três semanas (Gazêta, 2006, p.27). Nesse caso, ou o doente chegava curado, ou não chegava. A possibilidade de contágio externo advinha de os viajantes portadores do vírus estarem em comitiva grande o suficiente para que contaminassem gradativamente todos os membros até transmiti-lo a uma comunidade ou de alguém trazer do exterior algum material (roupas, sapatos, livros etc.) que contivesse o vírus da varíola.

No século XIX, Goiás era uma das províncias com os menores índices demográficos no Brasil: 149 mil habitantes, em 1872, apenas 1,6\% da população brasileira, que atingia 10 milhões de habitantes (Palacin, Moraes, 2001, p.65). Ainda em 1872, essa população estava dividida em meros 26 municípios, não havendo nenhuma cidade com população superior a 10 mil habitantes.

Outra característica de Goiás nos séculos XVIII e XIX é o isolamento geográfico. Devido ao fato de os dois maiores rios - Araguaia e Tocantins - banharem a parte menos povoada de Goiás (o norte) e correrem em direção ao Pará, região que tinha pouco a oferecer em termos de intercâmbios comerciais e demográficos, a comunicação com o exterior era feita pelas antigas estradas coloniais que iam em direção a Salvador e ao Rio de Janeiro; estradas precárias, utilizadas basicamente pelos tropeiros que realizavam o comércio com as demais regiões do Brasil. A viagem a Goiás era, portanto, perigosa e longa. O historiador Luís Palacin (1994, p.124) afirma que uma viagem rápida, com trocas frequentes de animais, realizada no período da seca, entre a capital de Goiás e a cidade de Salvador ou Rio de Janeiro durava em torno de três meses, tempo mais do que suficiente para um eventual portador do vírus da varíola morrer ou se recuperar no caminho, antes de chegar a Goiás.

Por isso, foram raros os surtos epidêmicos de varíola nos séculos XVIII e XIX, em Goiás. O cronista Alencastre (1979, p.342) afirmou que, durante a administração do capitão-geral Fernando Delgado, "Tendo a varíola invadido o sul de Goiás em 1811, e atacado o arraial de Meia Ponte, mandou estabelecer um cordão sanitário, para evitar, como de fato conseguiu, que o mal se propagasse, e fosse à capital, como em 1771, e fizesse os grandes estragos que então produzira".

As poucas informações disponíveis sobre essa epidemia de varíola ocorrida em 1771 dão conta de que provocou grande mortandade entre os indígenas caiapós, aldeados em São José de Mossâmedes. Já a epidemia que atingiu Meia Ponte, em 1811, é mais conhecida, graças a um poema de autoria de Florêncio Antônio da Fonseca Grostom, que abordou o surto epidêmico em suas estrofes.

A descrição que o poeta faz da epidemia vai além do interesse literário. Na inexistência de jornais, o poema torna-se a principal fonte histórica sobre esse assunto. Por meio dele, fica-se sabendo, por exemplo, que a epidemia era considerada a "justa ira de um Deus Onipotente" (Grostom, 1982, p.84); que os sintomas da doença eram suor frio e febre; que os doentes se debatiam se se tratasse de epidemia de "sarampões impedernidos", "sarnagem" ou "bexiga". O fato de Joaquim Alves de Oliveira, o homem mais rico de Goiás, ser o principal 
homenageado do poema é significativo: revela que, diante da fraqueza do Estado, traduzida na falta de médicos e hospitais, os particulares abastados assumiam os encargos financeiros e os eventuais lucros políticos com as tragédias.

O poeta utiliza imagens fortes para narrar a epidemia, como pode ser observado na descrição do aspecto do doente:
Em corruptas matérias se transforma
Líquido sangue, que das veias corre, De dia, em dia às pústulas reforma
O humor fero que a peçonha escorre:
A face inchada perde a humana forma
A cada passo vive o enfermo e morre,
Olhos, boca, narizes e garganta
Uma só face tem uma só planta.
(Grostom, 1982, p.86, 18aㅡ estrofe).

As pústulas e o rosto inchado corroboram a hipótese de ser uma forma grave (major) da varíola que atingiu Meia Ponte. O poeta continua descrevendo o pânico da população diante da epidemia, agravado pelo aparecimento de um eclipse do sol:

Negra nuvem no Céu nos aparece,

Brusca o tempo, e a luz nos tira e oculta,

O sol se eclipsa, e Érebo parece,

Em profundas cavernas nos sepulta:

Sobre as serras o manto escuro cresce.

A noite em provas passa, e se consulta

Ficam todos confusos deste acaso,

Não concede o pavor nem mais um prazo.

(Grostom, 1982, p.86, 10ª estrofe).

A concomitância de grandes tragédias e eclipses é tema recorrente na literatura antiga, remontando à narrativa de Tucídides sobre a peste que acometeu Atenas. No dia 24 de março de 1811, houve um eclipse solar visível em grande parte do continente sul-americano ${ }^{5}$; não se sabe, porém, se ele coincidiu com o período do surto epidêmico ou se o poeta forçou a concomitância para dramatizar sua narrativa. Considerando que a varíola incide mais no inverno do que no verão (Gazêta, 2006, p.13), é possível que o surto tenha realmente ocorrido no mês de março, quando ainda se tem um período chuvoso em Goiás, reforçando a plausibilidade do verso "negra nuvem no Céu nos aparece".

Grostom não quantifica infectados nem óbitos, mas descreve a dor de uma família abalada pela morte do filho doente:

A mãe exangue em fluxos desatados

Abraça o caro filho estala, e morre,

O filho ao amado Pai vê falecido,

Com suas mãos sepulta esmorecido.

(Grostom, 1982, p.88, 24ㄹ estrofe).

Depois desse surto de 1811, não se encontrou nenhuma referência, nos relatórios anuais dos presidentes de província (e posteriormente de estado) e em qualquer outra fonte documental, 
a surtos epidêmicos de varíola em Goiás no século XIX. Pelo contrário, em 1850, o presidente da província Eduardo Olímpio Machado teve a felicidade de afirmar que "a Providência Divina nos tem favorecido, preservando esta província do flagelo das bexigas, de que se acha isenta desde o ano de 1811" (Goiás, 1850, p.48).

Houve apenas um boato de um pequeno surto, em agosto de 1873, quando o presidente Antero Cícero de Assis recebeu comunicado do juiz de Boa Vista - atual Tocantinópolis (TO) -, localidade às margens do rio Tocantins no extremo norte da província, informando que o lugar estava na iminência de ser invadido pela varíola, proveniente dos ocupantes dos botes que subiam o rio, vindos do Pará. Posteriormente o presidente recebeu novas notícias de que outras povoações marginais ao rio também estavam contaminadas pela doença. Diante disso, ele resolveu abrir crédito de cerca de quatro mil contos de réis e enviar dois soldados com dinheiro, medicamentos e vacinas para as localidades atingidas. Foi recomendado também o isolamento dos suspeitos de contaminação para que a varíola não descesse para o sul da província. Em janeiro de 1874, um dos soldados enviados retornou à capital, informando que felizmente "a varíola não chegara a grassar nas referidas povoações" e que as pessoas da tripulação contaminada dos botes provavelmente "sucumbiram às margens do rio" (Goiás, 1874, p.29). Esse alarme falso esclarece algumas questões acerca da varíola em Goiás. O valor elevado da quantia colocada à disposição para ser gasta com a epidemia demonstra o quanto ela era temida. ${ }^{6}$ Além disso, até as malas do correio provenientes do norte eram desinfetadas. Um guarda nacional daquela região teve o azar de visitar a capital nesses dias e passou pelo constrangimento de ser examinado por dois médicos e de ser acusado, injustamente pelos jornais, de ser portador do vírus da varíola. Demonstra também o quanto eram limitadas as ações do poder público: o socorro só chegou a Boa Vista seis meses depois da suspeita de varíola; portanto, foi por puro acaso que a doença não se espalhou pelo norte da província nessa ocasião.

Essa situação de conforto em relação à varíola modificou-se, no entanto, a partir do final do século XIX, quando houve gradativo melhoramento das estradas e dos meios de transportes, e o aumento demográfico decorrente da imigração. O marco dessas transformações estruturais foi a chegada dos trilhos da estrada de ferro, a partir de 1914, e a ocupação econômica de novas áreas, como o sudoeste e a região do Mato Grosso goiano. Como reflexo dessas transformações, houve considerável aumento no número de municípios: de meros 26 em 1872 passaram a 49 em 1920 (Bertran, 1978, p.80). A população de Goiás, graças à imigração, aumentou de 255 mil habitantes, em 1900, para 511 mil em 1920 (Palacin, Moraes, 2001, p.93), tendo a média de crescimento demográfico goiano, pela primeira vez, sido maior do que a do Brasil (Silva, 2001, p.108).

A quase duplicação dos municípios provocou forte diminuição das distâncias entre eles, favorecendo a disseminação de doenças epidêmicas; o fluxo constante de imigrações e o aumento das trocas comerciais com regiões vizinhas também favoreceram a entrada de vírus epidêmicos. O interessante é que os próprios contemporâneos perceberam essa nova realidade. O presidente do estado, José Xavier de Almeida (Goiás, 2003, p.136), procurando sensibilizar os deputados da necessidade de se organizar o serviço sanitário de Goiás, afirmou "que a aproximação de vias férreas e o movimento imigratório de população estrangeira serviriam de veículos aos germens de moléstias ainda desconhecidas em nosso Estado, cuja invasão devemos evitar, empregando os processos profiláticos aconselhados pela ciência". 
A partir do final do século XIX, portanto, Goiás já não possuía a 'quarentena natural' que o livrou por muito tempo da varíola.

Essa vulnerabilidade de Goiás a surtos epidêmicos de varíola ficou evidente, em 1904, no arraial de Campinas. O lugarejo surgiu em 1810, situando-se em um local de passagem para a capital da província. Apesar disso, seu crescimento demográfico foi bastante lento. Já em 1890 o viajante Oscar Leal (1980, p.37) deixou o seguinte relato sobre o povoado: “às quatro horas da tarde passamos pelo arraial de Campininha, o lugar mais insignificante em todo o sul de Goiás". O lugar dinamizou-se um pouco quando, quatro anos depois dessa descrição, os padres da ordem redentorista, provenientes da Alemanha, estabeleceram-se no povoado para tomar conta da famosa romaria do Divino Espírito Santo que acontecia em Barro Preto (atual Trindade).

Além disso, a partir de 1896 a estrada de ferro Mogyana estendeu seus trilhos até a cidade mineira de Araguari, distante 55 léguas de Campinas. Com isso o fluxo de comércio e de pessoas entre as cidades do Triângulo Mineiro e a capital de Goiás passava, agora, preferencialmente por Campinas, que sofreu significativo desenvolvimento comercial e demográfico, sendo elevada à categoria de vila em 1907 e à de cidade em 1914. O progresso, contudo, tem seu preço, que foi alto para os habitantes do lugar. Antes de 1896, o final de linha da Mogyana era em Uberaba, distante de Campinas 80 léguas, que eram percorridas a cavalo em período médio de 13 dias. Depois desse ano, o tempo de viagem foi reduzido para até sete dias. Com isso aumentou a possibilidade de propagação da varíola por parte de pessoas provenientes de outros estados, principalmente da Capital Federal, palco de vários surtos epidêmicos. De fato, nesse período, essa região de Goiás foi afetada por três surtos de varíola: 1904, 1910 e 1926.

O mais conhecido deles é o de 1904, graças ao detalhado relatório do doutor Laudelino Gomes de Almeida, médico contratado pelo governo para controlar a epidemia. Segundo ele, a varíola chegou a Campinas da seguinte forma:

Surgia festeiro e alegre o ano de 1904.

Infelizmente, porém, não havia janeiro decorrido por completo, quando um homem, alquebrado de forças, arrastando-se febril, e com erupção pelo corpo, abrigara-se em uma meia-água aberta numa casa em arcabouço, possuindo só a cobertura e uma parte onde morava uma família, marido e mulher, em frente a um paiol de milho de propriedade do senhor Deocleciano Antônio da Silva, moço distinto, por todos os motivos, atual subdelegado de polícia, cargo que exerce com geral aplauso e onde se conduz com fidalguia, negociante e exemplar pai de família.

Nesta casa esteve o viajante um dia, transferindo-se depois para o paiol. No outro dia, soube-se chamar o forasteiro José Alves, e ser praça do exército, procedente do Rio de Janeiro, com destino à Capital Goyana para incorporar-se ao destacamento ali postado.

Passou-se isso em 8 de janeiro.

No dia 17 do mesmo mês, melhor, prosseguiu em sua jornada, acompanhado de uma mulher de cor preta. O seu corpo tinha sido invadido por uma erupção que começava a secar.

A varíola, pela primeira vez transportada para essas paisagens, era então desconhecida completamente e as pessoas, que viram e trocaram palavra com o doente, acreditaram-no vítima de umas cataporas bravas, que diziam estavam grassando concomitantemente com a coqueluche pelas redondezas (Goiás, 1904) 
Nove dias depois da partida do forasteiro, a varíola manifestou-se num rapaz que convivera com o enfermo e, nos próximos 13 dias, infectou mais duas pessoas. A população só foi saber da natureza da doença desconhecida quando

Dois viajantes italianos, de passagem por Campinas, onde tencionavam pousar, vendo o Senhor Augusto Maria do Carmo doente, com quem trocaram palavra e a quem interrogaram pela moléstia que nele se tinha apresentado, pela erupção confluente no seu rosto, desconfiaram e foram-se evitando Campinas, em disparada. $\mathrm{O}$ alarme da bexiga ecoou aos quatro ventos.

O pânico não podia ser maior, e quem pôde retirar-se, não deixou de fazê-lo, ficando no arraial pouca gente. Em início de fevereiro, a 8, teve o Governo notícias de que reinava em Campinas, uma doença que muito se assemelhava a varíola.

Isso se dava em Campinas, e o terror invadia as populações vizinhas e as quais puseram em prática rigorosos e despóticos cordões sanitários.

Destruíram pontes, impediram as estradas e deixaram Campinas entregue ao maior abandono (Goiás, 1904).

Naquele período, a varíola grassava em várias cidades importantes do Brasil, incluindo a Capital Federal. Em Goiás, no entanto, a doença não aparecia desde 1811, o que explica a dificuldade de seu diagnóstico. Por isso as autoridades temiam que a propagação da doença "pelo Estado e principalmente nesta Capital, será de consequências funestíssimas e aterradoras, visto como o nosso serviço sanitário estadual ainda não está organizado e a nossa Capital não possui nenhuma das condições higiênicas" (Ofício..., 19 mar. 1904).

Diante disso, o presidente do estado, Xavier de Almeida autorizou a abertura de um crédito extraordinário de aproximadamente cinco contos de réis ${ }^{7}$, isolou Campinas com cordões sanitários, telegrafou ao Instituto Vacínico Municipal do Rio de Janeiro, pedindo com "urgência mil tubos de vacina antivariólica para esta capital e cem [para cada uma das 29 localidades circunvizinhas a Campinas" (Goiás, 2003, p.139).

Na tentativa de evitar a contaminação dos vilaboenses, quando o soldado José Alves e sua companheira chegaram à cidade de Goiás, no dia 26 de janeiro, ainda apresentando sintomas da varíola, imediatamente foram enviados, pelo comandante do batalhão, ao médico Rodrigues de Moraes que, mesmo sem conseguir determinar se a doença que o acometia era realmente varíola, sugeriu que ele fosse isolado. Desse modo, José Alves e sua companheira foram postos em quarentena, num rancho rudimentar, situado a mais de uma légua da cidade, sob a vigilância de dois soldados. A mulher e os guardas contraíram a varíola, sendo que ela faleceu no dia 8 de fevereiro de 1904 (Goiás, 2003, p.137).

Quanto aos habitantes de Campinas, o governo estadual enviou, em fevereiro, o soldado Tomaz Bispo Pinheiro, com uma série de medicamentos tradicionalmente utilizados para o tratamento e desinfecção das residências: óleo de rícino, creolina, folhas de jaborandi e cal. ${ }^{8}$ Nesse mesmo mês de fevereiro, apareceram oito novos casos de varíola, sendo um fatal; em março, mais oito, dois fatais. Tantas mortes e doentes levaram o padre José Wendel, superior dos redentoristas, a reclamar providências mais efetivas por parte do governo do estado. Diante disso, resolve-se contratar o médico recém-formado Laudelino Gomes de Almeida para cuidar da situação de Campinas. Ele chegou ao lugarejo, no dia 26 de março, permanecendo no cargo até 20 de maio, quando foi exonerado (Ofício..., 11 jun. 1904). 
Foram longos e penosos os dias para os habitantes de Campinas que, oficialmente, ficaram isolados de 19 de janeiro a 21 de março. As pontes de acesso foram destruídas, e soldados vigiavam o caminho para impedir a entrada e saída de pessoas. Durante esse período, segundo informações dos padres redentoristas,

Fecharam-se as casas, e quem pôde fugir fugiu... Tendo os negociantes abandonado o lugar, faltava o sal e iam aos padres, mediante licença do comandante, pedir, emprestado ou comprar. A maior parte não tinha dinheiro e os que iam emprestar nunca mais restituíram. Dávamos aos pobres o sustento, dando-lhes feijão, arroz, açúcar, mandioca e dinheiro para comprar toucinho... Os soldados encarregados de distribuir esmolas aos pobres praticavam abusos, guardando para si donativos e leites (Crônicas..., 1903-1907).

A atuação dos redentoristas durante a epidemia contribuiu para a dissipação das desconfianças naturais que os grupos pequenos e fechados nutrem em relação a estrangeiros. Um desses padres chegou a contrair varíola ao atender os doentes. A situação de penúria só não deve ter sido pior, por causa da autossuficiência da economia sertaneja por meio do armazenamento de cereais e a utilização complementar de frutos e caça do cerrado. Mesmo assim, o impacto psicológico da quarentena e o estigma de uma doença temida devem ter sido marcantes. Ilustrativo do pânico foi uma carta escrita por um dos sitiados a seu primo, em que desabafa: "Estamos cercados, em curta distância por todos os lados e, portanto, privados de qualquer socorro!" (Carta..., 17 fev. 1904). Sob a perspectiva numérica, a epidemia de varíola em Campinas não pareceu tão trágica: foram 18 doentes e três mortos. A máxima das ciências econômicas de que a raridade cria valor pode, no entanto, ser aplicada também às epidemias: a percepção de risco é proporcional à raridade da manifestação epidêmica, o que explica o "terror que invadiu a população de Campinas e todos os lugares circunvizinhos, em se tratando de uma enfermidade desconhecida entre nós" (Ofício..., 19 mar. 1904). A partir desse acontecimento, contudo, a varíola se tornaria forçosamente cada vez mais familiar à população goiana.

Em 1910, é provável que um surto da doença tenha atingido a cidade de Goiás. Houve intenso questionamento a respeito de se tratar realmente de varíola ou de varicela. $\mathrm{O}$ jornal O Planalto, da cidade de Santa Luzia, publicou em 5 outubro de 1910, notícia referente a casos de varicela, "variloide ou bexiga, que ... fazia-se tão pouco caso, tem ... levado à sepultura para mais de cinquentas pessoas" (De Goiás, 5 out. 1910). Posteriormente, o periódico informou tratar-se de varíola: "a dona varíola, com os pés de lã, sorrateiramente vai-se introduzindo aqui, sem que o povo dê por isso" (De Goiás, 12 out. 1910). Sobre essa controvérsia, o presidente do estado admitiu que apenas um caso foi de varíola "em uma criança que jamais daqui saíra"; já "vários outros casos têm aparecido fora e dentro da capital, os facultativos e o doutor chefe da higiene municipal diagnosticaram como varicela" (Goiás, 15 mar. 1911, p.9). Essa controvérsia se explica pela dificuldade de a ciência médica da época diagnosticar a varíola. Houve, aliás, entre 1910 e 1913, intensa polêmica entre dois importantes médicos de São Paulo sobre o alastrim ser ou não varíola. (Teixeira, 2000). A confusão entre varíola e varicela deve-se ao fato de que "A varíola sempre foi tida como uma das doenças mais contagiosas e perigosas, porém, no século XX, predominou a varíola minor, que não passava, na prática, de uma doença um pouco mais severa que a varicela. A similaridade era tão grande, que, no Brasil, apelidava-se a $v$. minor de 'varicela', enquanto a verdadeira varicela era denominada 'catapora'” (Gazêta, 2006, p.28). 
Em 1926, a região próxima a Campinas foi novamente palco de forte epidemia de varíola, e dessa vez a principal localidade atingida foi Trindade, famosa por abrigar uma das maiores romarias religiosas do Centro-Oeste. Segundo os padres redentoristas, por causa do surto epidêmico, "a vila perdeu sua vida; romeiros a evitavam e por meses ninguém mais a procurou; os próprios moradores do lugar a abandonaram: a miséria e a pobreza chegaram ao auge" (Crônicas..., 1926-1939, p.19).

O ano de 1926 foi bastante propício à eclosão de doenças epidêmicas. A passagem da Coluna Prestes e dos soldados legalistas em seu encalço prejudicou a produção agrícola, pois os camponeses ou fugiam para o mato, quando da passagem da Coluna, ou eram recrutados pelos legalistas para perseguir os revolucionários. Além disso, os integrantes de ambos os grupos costumavam apropriar-se dos escassos alimentos e medicamentos da população local. ${ }^{9}$ A dificuldade de acesso aos alimentos deve ter baixado a resistência imunológica da população, facilitando o contágio pelo vírus da varíola que circulava abundantemente no lugar inflado de estrangeiros. Com isso, o trinômio maligno guerra, fome e peste contribuiu para que a epidemia de 1926 deixasse números eloquentes em vista dos padrões goianos: "dezenas e dezenas de pessoas foram vitimadas e mais ou menos umas 70 sucumbiram" (Crônicas..., 1926-1939, p.19).

Dessa vez, seja porque a varíola já se tornava relativamente banal, seja devido à prioridade dada às providências de defesa contra os revolucionários da Coluna Prestes, o governo estadual não deu a mínima assistência à população de Trindade. Novamente, foram os redentoristas - graças a suas boas relações com o Instituto Butantã de São Paulo, ao qual forneciam periodicamente animais peçonhentos - que conseguiram mil tubos de vacina para distribuição à população de Campinas e Trindade.

Apesar de bastante próximo a Trindade (20 quilômetros), Campinas, dessa vez, não foi afetada pela varíola. Segundo os redentoristas, "a cidade nada sofreu por uma proteção especial de Nossa Senhora da Conceição” (Crônicas..., 1926-1939, p.20). Além da proteção da santa, podem ter contribuído para a suposta imunidade dos habitantes de Campinas o trabalho de vacinação realizado em 1904 pelo médico Laudelino Gomes de Almeida e a imunidade natural dos sobreviventes à doença.

Ainda em 1926, na longínqua São José do Duro - atual Dianópolis (TO) -, a varíola também fez estragos. O lugar era palco de um conflito entre os jagunços dos coronéis locais e a polícia goiana, que fez com que muitos moradores abandonassem a região. ${ }^{10}$ Entre eles estava o fazendeiro Antônio Póvoa (1975), sua mulher e filhos, que após o término da disputa, retornam de Barreiras (BA) para sua fazenda no município. Sua filha fora acometida por doença que se pensou inicialmente tratar-se de catapora, mas depois confirmou-se ser varíola. Contaminando primeiro seus parentes e amigos, logo a doença se espalhou pelas vizinhanças de São José do Duro.

As cenas que se seguiram foram comoventes, mesmo para São José do Duro, um lugar marcado por grandes tragédias. É ilustrativo o caso de Justino Bento, o oficial de justiça, que passou pela provação de ter que dar ordem de prisão ao poderoso e truculento Abílio Wolney e conseguira passar incólume à guerra entre o coronel e a polícia. Vivia, desde então, num casebre nas terras de propriedade de Antônio Póvoa e, por isso, foi intimado pelo fazendeiro a cuidar do enterro de um de seus filhos vitimado pela varíola. Temendo o pior, Justino abraçou 
seus filhos, distribuiu-lhes seus poucos bens e foi cuidar do enterro do filho do fazendeiro. Terminada a missão, recusou-se a retornar a sua casa, pois preferia morrer a contaminar sua família. De fato, Justino morreu vitimado pela doença, e seu corpo foi jogado no rio Palmeiras, já que ninguém teve coragem de cuidar de seu enterro (Póvoa, 1975).

Outra tragédia abateu-se sobre a família de um camponês conhecido por Higino. Morreram ele, a esposa e sete dos seus nove filhos. Os dois sobreviventes foram encontrados esfomeados, junto aos cadáveres em putrefação, disputados pelos urubus e cães. Outra família, de oito membros, foi totalmente aniquilada pela varíola, e seus cadáveres também foram devorados por cães e aves de rapina. Diante dessas e outras cenas, a vizinhança de São José do Duro foi tomada pelo pânico. Os doentes foram abandonados à própria sorte ou ficaram ao encargo de pessoas vacinadas ou altruístas. As conversas com os suspeitos da doença eram realizadas sempre "a favor do vento", em prudente distância. A população da área afetada era de mais ou menos 200 pessoas. Sucumbiram 64, ou seja, mais de $30 \%$, proporção equivalente ao que comumente se atribui às vítimas da Peste Negra. A pobreza, a falta de recursos sanitários, a desnutrição de uma região arrasada por conflitos armados são responsáveis por tamanha mortandade (Póvoa, 1975).

Enfim, esses surtos epidêmicos de varíola que aconteceram em Goiás no século XX são relevantes para se compreender a especificidade das ações e atitudes regionais em relação à doença. Enquanto a varíola era um problema sério no Brasil do século XIX, em Goiás houve apenas um surto da doença nesse período; a década de 1920, entretanto, em que a varíola perdeu seu poder de letalidade e de transmissão, deixando de ser um problema sanitário relevante (Gazêta, 2006, p.60), em Goiás foi o período de maior incidência e letalidade da doença.

\section{O medo da vacina contra varíola}

A história da resistência popular à vacina antivariólica é assunto bem abor-

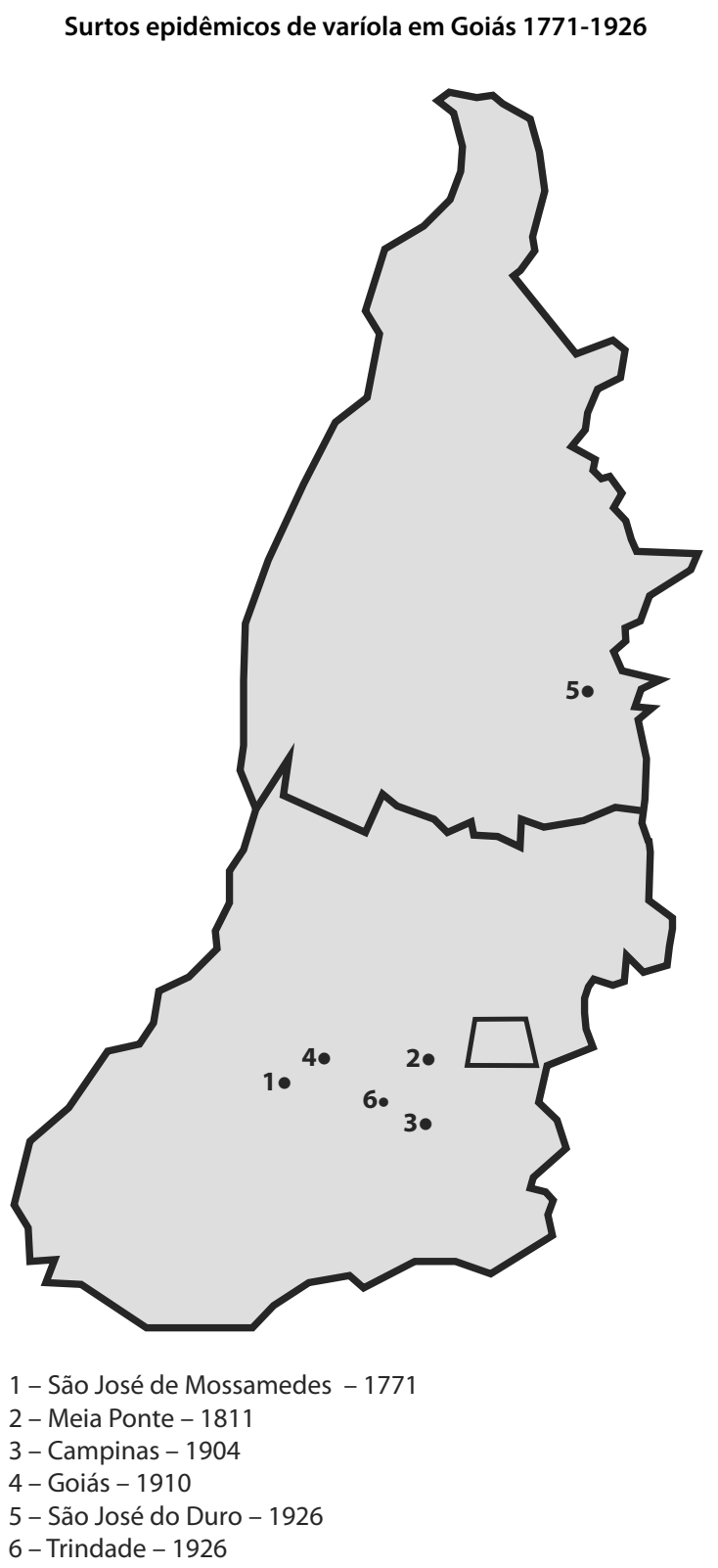


dado pelos historiadores, principalmente a famosa Revolta da Vacina ocorrida em novembro de 1904 na cidade do Rio de Janeiro. O acontecimento é explicado de formas bastante diversificadas: das posturas racionalistas e preconceituosas dos historiadores em relação aos motivos das classes populares até as que procuram compreender os valores culturais dos que participaram da revolta. Dentre as últimas, destaca-se o livro de Nicolau Sevcenko (1984), que atribui o episódio à resistência popular à racionalidade burguesa que se estava implantando no Rio de Janeiro. Outro autor clássico sobre o tema é José Murilo de Carvalho (1987, p.131), que viu a revolta como resultado da "primeira campanha publicitária de êxito no país" promovida pela oposição ao governo de Rodrigues Alves que conseguiu sensibilizar a população por meio de argumentos morais: "O que talvez mais tenha atingido a população foi o tom moralista emprestado à campanha .... Buscou-se explorar a ideia da invasão do lar e da ofensa à honra do chefe de família ausente ao se obrigarem suas filhas e mulher a se desnudarem perante estranhos".

Segundo Leonardo Pereira (2002, p.24) e Sidney Chalhoub (2004, p.100) as motivações morais são mais da classe letrada aburguesada do que da massa de trabalhadores. Ambos buscam explicar a resistência da população à vacina levando em conta as práticas culturais afro-americanas, bastante influentes no Rio de Janeiro da época:

Sabemos talvez agora a fonte do 'horror' que os médicos e suas vacinas inspiraram aos populares, ao menos àqueles dentre eles que adoravam Omulu [orixá relacionado a varíola] e temiam provocar sua ira: obstaculizar a ação dessa divindade era provocar mais devastação e morte, uma noção já presente na versão do culto entre os daomeanos, e que laboriosamente fizemos aportar ao Rio do século XIX (Chalhoub, 2004, p.151).

Mesmo levando-se em conta que muitos de seus moradores [do bairro da Saúde] não necessariamente compartilhavam a crença nos orixás, a predominância ali existente das tradições religiosas afro-brasileiras fazia daquele um local privilegiado para o surgimento de uma oposição mais sistemática à vacina (Pereira, 2002, p.24).

Essas duas obras explicam a oposição dos cariocas à vacinação obrigatória dentro de uma perspectiva chamada pelos historiadores de longa duração. A resistência popular à vacinação antivariólica foi centenária em todo o Brasil. Em Goiás não foi diferente: enquanto a elite administrativa esforçava-se para implementá-la com eficiência, a população a temia e a evitava.

Indicativo desse repúdio foi o quase motim com que a população da cidade de Goiás, em 1831, pressionou o presidente da província Miguel Lino de Morais e seus familiares para que se retirassem, em quarentena, a uma distância de três léguas da cidade, pelo fato de alguns deles terem sido vacinados (Brasil, 1980, p.65). Até a Câmara de vereadores oficiou ao presidente pedindo sua retirada da cidade, que só não aconteceu graças à interferência do bispo e de outras autoridades. Até onde se sabe foi a primeira inoculação da vacina em Goiás, e a população temia que a vacinação provocasse uma epidemia na cidade.

Esse acontecimento demonstra a confusão entre vacinação e variolização, inoculação ou transplantação, que "consistiam em implantar no homem sadio o vírus variólico contido na secreção retirada das pústulas de pessoas doentes, objetivando-se provocar a doença em sua forma mais branda, evitando-se a forma mais grave" (Gazêta, 2006, p.31). Esse processo era conhecido há milênios na Ásia e na África, mas apenas no início do século XVIII foi aplicado na Inglaterra e divulgado em outras regiões da Europa. É provável que os portugueses só 
tivessem conhecido a variolização no final do XVIII, quando já havia sido criada a vacinação por Jenner. Chalhoub (2004, p.127) acredita ser possível que a variolização fosse "prática recorrente no país, pois só uma experiência prévia relativamente generalizada com o método poderia justificar que as pessoas soubessem exprimir tão bem os seus riscos, e então se recusar à vacina porque, sendo assim, 'a vacina seria com efeito varíola'” (destaque do original). Nesse sentido, a recusa à vacina se explicaria pelo fato de as pessoas terem conhecimento da variolização, mas não acreditarem em sua eficácia, temendo por isso a vacinação. Isso explicaria a confusão da Câmara, majoritariamente branca, supondo que a vacinação - prática de risco zero - pudesse propagar a varíola.

Chalhoub (2004, p.133) acredita também que, clandestinamente, a variolização fosse prática mais ou menos disseminada no Brasil, já que se vinculava às tradições africanas. Nesse sentido, em Goiás foi registrado caso raro que demonstra a persistência secular dessa prática popular. Na epidemia de 1926 em Trindade, o cronista redentorista alemão deparou-se com a prática da variolização, mas seu etnocentrismo levou-o a denominá-la "verdadeira loucura": "Com a faina de vacinar praticaram algumas verdadeiras loucuras, não só serviam-se do pus das fístulas ocasionadas pela vacina, mas em Trindade chegou um tal a vacinar-se com o pus de um bexiguento: fato real" (Crônicas..., 1926-1939, p.20).

É fato que a confusão entre variolização e vacinação foi bastante pronunciada em Goiás na primeira metade do século XIX, o que se evidencia na fala de primeiro de maio do presidente Antônio da Silva Gomes: “Ocupando muito a minha atenção a esse interessante ramo do Público Serviço, não cessarei de empregar, mediante a cooperação dos juízes de direito das comarcas, os precisos esforços para dissipar do espírito da população a falsa crença de que a vacina, longe de ser um poderoso preservativo do mal, é a matéria variolosa" (Goiás, 1851, p.37).

No início parece que a resistência à vacinação antivariólica era prática disseminada em Goiás. Em 1839, o então presidente da província, padre José de Assiz Mascarenhas, discursando perante o Legislativo goiano, disse em tons de súplicas: "Rogo-vos mui incessantemente [que] apliqueis toda a vossa influência e todos os vossos esforços para acreditar a vacina, e até o vosso exemplo, fazendo vacinar as pessoas da vossa família, o povo se persuadirá da necessidade da vacina e seus admiráveis efeitos" (Goiás, 1839, p.14).

Tal pedido insinua que a desconfiança em relação à vacina era, nesse momento, vigente até entre a elite econômica e letrada e não 'coisa do povo'. Posteriormente a elite econômica mais intelectualizada, principalmente a parcela que habitava a capital, começa a aceitar a vacina. Antônio da Silva Gomes afirmou, em 1851, que a vacinação era bem-sucedida na cidade de Goiás "por não ser tão pronunciada como em outros lugares a repugnância ao emprego de tão seguro preservativo da peste assoladora" (Goiás, 1851, p.36). Seu sucessor, Francisco Mariani, afirmou orgulhosamente que, na capital, “os espíritos mais esclarecidos" já haviam compreendido "o valor deste precioso preservativo de um dos mais terríveis flagelos, que oprimem a humanidade", embora, nas demais localidades, predominasse, em relação à vacina, "uma repugnância que faz tremer" (Goiás, 1853, p.22). Outros municípios, além da capital, em que se alcançava algum sucesso na prática da vacinação, eram Bomfim, Meia Ponte, Santa Luzia.

Foi forte, portanto, a resistência popular à vacina antivariólica em Goiás. Creditá-la aos preconceitos ou 'falsas ideias' populares como faziam os presidentes da província e 
seus auxiliares não satisfaz ao historiador. A explicação do medo da vacina envolve outros elementos, além da confusão entre vacinação e variolização.

Em primeiro lugar, o processo de vacinação, além de dolorido, era demorado e complicado. $\mathrm{Na}$ forma de linfa, a vacina era importada do Rio de Janeiro. A longa distância e o calor deterioravam com frequência o material. O presidente José de Assis Mascarenhas e o médico Vicente Moretti Foggia fizeram "algumas experiências" (Goiás, 1840, p.6), mas sem nenhum resultado. O que eles chamam de experiência consistia em injetar o material em pequenas incisões feitas no braço e esperar que, depois de alguns dias, aparecesse uma pequena pústula, indicando o sucesso da vacinação.

Essa descrição refere-se à chamada vacina jenneriana ou humanizada, na qual o cow-pox original da vaca era introduzido no homem e, a partir dele, a linfa ou o pus variólico era retirado e utilizado para novas inoculações em outros braços. Em 1840, passou-se a utilizar outro processo de vacinação, conhecido como vacina animal, em que se retirava a pústula da vaca e a inoculava diretamente no homem (Fernandes, 1999, p.20). No Brasil, a vacina animal só apareceu em 1887, graças à iniciativa particular do médico Pedro Affonso. No entanto, apesar de evitar o doloroso processo de retirada da linfa do braço, a vacina animal ainda era dolorosa e rudimentar, conforme indica a descrição da vacinação nas primeiras décadas do século XX:

Qualquer instrumento cortante ou perfurante servia para fazê-la, sem passar pela desinfecção e ainda de maneira exagerada. Fomos vacinados nos dois braços. Levando dois quadrados em cada um. Não apanhamos a doença, mas quase morremos da vacinação. No interior, onde não tinha médico, qualquer pessoa se alvorava em vacinador. Presenciamos vacinação com canivete, sem que tais instrumentos fossem, ao menos, lavados (Abreu, 1978, p.35-36).

Fator de incômodo para a população no processo de vacinação jeneriana era a necessidade de retorno ao comissário vacinador para que ele retirasse o pus e o injetasse no braço de outra pessoa, garantindo assim a continuidade do processo. Para obrigar o retorno, utilizava-se de multas e até da repressão policial, o que pode ter contribuído para desestimular a frequência da população arredia aos militares. Além disso, para a população rural que morava a grandes distâncias dos núcleos urbanos, o retorno era trabalhoso e inconveniente. A Tabela 1 permite uma noção estatística da questão do retorno para revacinação em Goiás nos primeiros anos da década de 1850 .

Tabela 1: Vacinados contra a varíola em Goiás, 1849-1852

\begin{tabular}{|c|c|c|c|c|c|c|}
\hline Anos & \multicolumn{2}{|l|}{ Vacinados } & \multicolumn{2}{c|}{ Não aproveitado } & \multicolumn{2}{c|}{ Não retornaram } \\
\hline 1849 & 1016 & $100 \%$ & 31 & $3,05 \%$ & - & - \\
\hline 1850 & 608 & $100 \%$ & 3 & $0,41 \%$ & 25 & $4,11 \%$ \\
\hline 1851 & 345 & $100 \%$ & 5 & $1,44 \%$ & 25 & $7,24 \%$ \\
\hline 1852 & 184 & $100 \%$ & 3 & $1,63 \%$ & 5 & $2,71 \%$ \\
\hline
\end{tabular}

Fonte: Relatórios dos presidentes da província de Goiás (Goiás, 1850, 1851، $1852,1853)$

É bem provável que os índices de retorno e aproveitamento estejam inflados. Constantemente criticados por "falta de conhecimentos profissionais" (Goiás, 1856, p.12), os comissários vacinadores paroquiais não teriam dificuldade em alterar os dados dos relatórios a fim 
de minimizar a acusação de incompetência. Enquanto na Corte, em 1850 (Chalhoub, 2004, p.113), a taxa dos que não retornaram foi de cerca de 30\%, em Goiás foi de apenas 4,11\%: uma incoerência gritante. Além disso, os dados da tabela insinuam a aceitabilidade da vacina em Goiás. Na Corte, entre 1846 e 1850, a taxa média de vacinação foi de 16,4 para cada mil habitantes (p.113); em Goiás, entre 1849 e 1852, a média foi de 5,67 vacinados em cada mil habitantes, número mais coerente com as condições sociológicas e materiais da província na época. Quanto aos índices de aproveitamento, por sua vez, eles parecem muito altos e contradizem as reclamações dos presidentes das províncias de que "chegando aqui o fluido deteriorado, talvez pela demora da viagem, a aplicação dele tem sido ineficaz" (Goiás, 1855 p.26).

Parece que a partir das últimas três décadas do século XIX, a confiança no poder curativo da vacina jenneriana não era a mesma dos anos 1830, quando, por exemplo, o presidente José de Assiz Mascarenhas afirmou que sua eficácia era "levada a um tal grau de certeza, que não há presentemente um fato em Medicina mais bem provado, ou mais certo do que aquele que estabelece o verdadeiro poder antivarioloso da vacina" (Goiás, 1839, p.13). De forma diversa, em 1870, um ofício do ministro do Império informava às autoridades goianas o "grande número de casos de varíola ultimamente ocorridos em indivíduos vacinados com o pus tirado braço a braço" (Ofício..., 28 jan. 1871). O motivo alegado para isso foi que a linfa importada da Europa já se havia desgastado devido às constantes inoculações. Em razão disso, alguns defendiam a revacinação, isto é, a necessidade de uma segunda vacinação. A prática foi adotada no Brasil e em Goiás, mas sem muito resultado se se levar em conta o que afirmou o presidente Souza Spinola: "a vacinação e a revacinação são feitas muito incompletamente" (Goiás, 1880, p.18). De acordo com Fernandes (1999, p.22), "se já era difícil convencer a população a vacinar-se, mais complexo tornava-se o convencimento no caso da revacinação, entendida como uma indicação de falha técnica na aplicação da primeira dose".

Na verdade, desde sua introdução no Brasil, a vacina contra a varíola foi alvo de controvérsias entre os médicos. Chalhoub (2004, p.115) mostra que o principal argumento dos médicos adversários da vacina era, além da sua ineficiência em alguns casos, a transmissão de doenças humanas (como a sífilis) e animais para o vacinado. Esses médicos eram minoria, mas, para desespero dos administradores públicos, faziam grandes estragos nas campanhas de vacinação. A população se apropriava desses argumentos, o que reforçava o medo da vacina.

O fato comprovado de que a vacina contra varíola poderia transmitir sífilis era um obstáculo sério para sua difusão. A sífilis era uma doença associada à moralidade: embora Gilberto Freyre (1996, p.319) tenha mostrado o quanto ela estava banalizada no Brasil colonial, sendo até vista como prova de virilidade masculina, no século XIX essa associação poderia provocar rubores e descontentamentos, principalmente entre os mais pudicos. Também a varíola vinculava-se à moralidade, mas à moralidade coletiva, no sentido definido por Susan Sontag (2002, p.76): "as doenças epidêmicas eram comumente usadas em sentido figurado como designativas de desordem social". A sífilis, portanto, era metáfora de um pecado individual relacionado à sexualidade, e a varíola era metáfora de um pecado coletivo. Nessa aritmética, alguns preferiram as cicatrizes da varíola às da sífilis. ${ }^{11}$

A origem animal da vacina, por sua vez, causava repulsa na população. Na Europa, chegou-se a afirmar que "a inoculação da vacina 'avacalharia' as pessoas, transplantando-lhes características do animal, além de transmitir doenças próprias dos animais para os indivíduos 
inoculados" (Fernandes, 1999, p.21; destaque do original). Havia boatos de crianças com "cara semelhante ao boi", notícias de pessoas que mugiam ou de tumores parecidos com chifres em pessoas vacinadas. É provável que em Goiás do século XIX, lugar de tanto gado, esses boatos exercessem forte efeito no imaginário coletivo. Em um dos seus contos, o escritor regionalista Bernardo Élis (2003, p.128) retrata essa intimidade suspeita de parte da população masculina goiana por meio da personagem sugestivamente denominada Joãoboi, meio "joão", meio "boi", que "não desapartava das vacas, principalmente das novilhas mais novas, pelo liso e carnes roliças". Nesse ambiente, a chamada vacina da vaca poderia suscitar a lembrança de pecados adolescentes, e sua recusa poderia ser prova de não comprometimento. O historiador deve ser cauteloso com esses fatos anedóticos, mas não deve subestimar seu impacto - ainda nos tempos da Revolta da Vacina, havia quem dissesse que o governo estava querendo envenenar a população com caldo de ratos (Pereira, 2002, p.110).

A vacina antivariólica contrariava as sólidas tradições religiosas populares existentes no Brasil. Tanto o catolicismo popular, como as religiões de matriz africanas viam na varíola, mais do que simples doença, uma intervenção sobrenatural. Padres chegaram a dizer que "tal invento era um presente de Satã e que vinha perturbar a marcha da natureza" (Chalhoub, 2004, p.145). Se a varíola é castigo, não cabe aos humanos interferir na justiça divina. Além disso, a possibilidade aberta pelo Iluminismo de os humanos controlarem seu destino e a natureza ainda não havia sido bem assimilada pela população. Predominava uma concepção fatalista da vida e da morte: não adianta e não é correto lutar contra as forças do destino. Quando chegar a hora, é impossível escapar da morte. Nesse sentido, a vacina era vista como um ato de velhacaria, contra as forças do destino. ${ }^{12}$

A vacina era, além disso, prática médica inovadora em relação à medicina popular e às práticas médicas pré-pasteurianas. Antes do século XX, a medicina visava mais expulsar coisas do corpo do que colocar nele substâncias estranhas: a escarificação ${ }^{13}$ visava expelir pelo pus os humores prejudiciais, a sangria era receitada para quase todo o tipo de doença, os purgantes e lavagem eram utilizados para qualquer tipo de cólicas, usavam-se muito também os suadouros e os vomitórios. Já a vacina nada visava expelir, mas inserir algo estranho no corpo.

Em 1866, os doutores Thomaz Cardoso de Almeida e Vicente Moretti Foggia recomendavam para os doentes de varíola: "uma larga sangria de braço (de libra e meia de sangue)", "sessenta sanguessugas sobre o estômago", "uma bebida sudorífera", "dois ou três purgantes de sal amargo" (Almeida, Foggia, 15 maio 1866) e dieta à base de arroz e caldo de galinha. A população valia-se dos mais inusitados tipos de medicamentos. Um dos mais exóticos era "Jasmim de cachorro, fezes deste animal (de cor branca, devido ao fato de serem puro cálcio, resultante dos ossos de que se alimentavam os cães), que moídas, se dissolviam na água. Em ocasião de varíola foi um santo remédio" (Rebello, 1987, p.38).

Considerando que novidade por si só é motivo de medo ${ }^{14}$, era compreensível, portanto, a desconfiança de uma prática inovadora que ia contra a tradição médica e contra as práticas da medicina popular.

Para a elite intelectual e política de Goiás, essa desconfiança da população em relação à vacinação antivariólica era sintoma de ausência de civilização. O presidente Mascarenhas, tentando convencer os deputados provinciais a aceitar a prática da vacina em 1839, argumentou que "este objeto tem sido julgado um dos mais importantes por todos os governos 
civilizados" (Goiás, 1839, p.14). Seis anos depois, outro presidente afirmava sobre a vacina perante a Assembleia Legislativa goiana que "não há nação civilizada que não [a] reconheça, e que deixe de usar deste importante preservativo" (Goiás, 1847, p.26). O presidente Aristides de Souza Spinola foi mais direto, relacionando a resistência à vacina aos costumes indígenas: "com a imprevidência do selvagem não se tem cuidado, ao menos, na inoculação do pus vacínico" (Goiás, 1880, p.18).

Jurandir Freire Costa (1979, p.132) mostrou que, no século XIX, a medicina higienista foi o principal instrumental ideológico que o Estado utilizou para normatizar a vida familiar brasileira, insuflando "a família abrir mão dos antigos hábitos em troca das formas de viver europeias". A medicina higienista deu precisão científica à categoria civilização, estimulando os administradores públicos a combater as práticas ditas não civilizadas de escravos, pobres, ciganos, indígenas, caipiras, considerados indivíduos fora do mundo civilizado da norma higiênica. Nesse sentido, a vacina antivariólica foi uma das primeiras tentativas do Estado de utilizar argumentos sanitários para promover a civilização.

Logo depois, a Sociedade de Medicina do Rio de Janeiro iniciou uma campanha contra a prática de enterrar corpos nas igrejas, visando "elevar o país à altura da civilizada Europa" (Reis, 1997, p.133). Como era de esperar, os presidentes da província de Goiás, com atraso e dificuldade, tentaram seguir as recomendações civilizadoras que vinham da Corte. Ainda em 1845, José Mascarenhas afirmava: “A majestade da Religião Santa que professamos, a higiene e a decência exigem soberanamente que os templos deixem de ser o receptáculo de cadáveres e vermes. É indispensável, que por toda a parte se façam cemitérios, e assim daremos uma prova de que não estamos tão atrasados na civilização, como querem alguns invejosos ignorantes" (Goiás, 1845, p.9).

Parece que os mencionados invejosos ignorantes eram mais numerosos do que o empolgado Mascarenhas imaginava. Em Goiás não houve nada parecido com os quebra-quebras urbanos, as "cemiteradas", ocorridos na Bahia, na década de 1830, contra os cemitérios (Reis, 1997, p.136); mas parece que houve também certa resistência, embora mais velada, a eles. Só isso explica o fato de a construção de um simples cemitério ter demorado tanto: o cemitério da capital foi inaugurado em 1858. Nos outros lugares de Goiás, a resistência continuava. Em 1874 Antero Cícero de Assis afirmava: "Segundo me parece esta é uma das Províncias do Império em que menos se tem conseguido evitar a inconveniente prática de enterramento nas igrejas, prática que não está a par de nossa civilização e tem sido abolida mesmo nos pequenos povoados de outras províncias" (Goiás, 1874, p.26).

Ele, aparentemente, tinha razão. Meia Ponte, rival da capital, só construiu seu cemitério em 1869. Aos poucos, entretanto, a prática de enterrar pessoas nas igrejas foi sendo eliminada em Goiás. A carta de uma leitora, Roseira Zelosa, publicada no jornal Matutina Meiapontense de 13 de novembro de 1830 já condenava essa prática: "No dia 2 de novembro do corrente... me achei na Catedral desta cidade de Goiás para enviar as minhas orações ao Todo-poderoso ..., quando de improviso me vi atacada do mais execrado fedor que fedia-se por toda a igreja ... Será crível que estejam alucinados, ou faltos de olfato para não sentirem o quão danoso é semelhante abuso para bem público" (citado em Oliveira, 2001, p.114).

Esse relato ilustra a afirmação de Norbert Elias (2001) de que a civilização não age apenas sobre o espírito, mas também sobre o corpo. A pacificação interna promovida pelo Estado gera 
comportamentos que repudiam quaisquer aspectos que lembram a violência, como é o caso do moribundo e do cadáver. Quanto mais integrada ao processo civilizador de uma sociedade, mais repúdio ela vai ter dos elementos que lembram a morte. "A decadência do organismo humano, o processo a que chamamos morrer, quase sempre é acompanhado de mau cheiro. Mas as sociedades desenvolvidas inculcam em seus membros uma grande sensibilidade aos cheiros fortes" (p.102). Isso explica por que o olfato 'civilizado' da Roseira Zelosa passou a achar insuportável o cheiro emanado das igrejas. Provavelmente seus contemporâneos não estavam "faltos de olfato", mas seus sentidos ainda não haviam sido domesticados pelo processo civilizador. Foi apenas quando emergiu um novo objeto, no sentido foucaultiano do termo, que as pessoas começaram a achar insuportável e perigoso o cheiro cadavérico das igrejas.

Nesse sentido, portanto, no Brasil e, especialmente em Goiás, lugar tido como nosologicamente perigoso, as medidas relacionadas à saúde e higiene foram utilizadas com frequência para implantar atitudes compatíveis com a civilização.

\section{Considerações finais}

Desde a década de 1970, a varíola inexiste, e essa inexistência tem implicações metodológicas relevantes para aqueles que pretendem abordá-la, pois os pesquisadores olhamna de um horizonte em que ela não mais existe, em que a saúde pública tem outra dimensão, em que a estética do corpo é muito mais valorizada, em que a própria morte é vista de modo diferenciado. Portanto, a compreensão da varíola implica uma tarefa hermenêutica em que há uma fusão dos horizontes do passado (no qual está a varíola) e do presente (no qual está o pesquisador) (Gadamer, 1997, p.458). Essa diferença de horizontes, longe de ser obstáculo, é fundamental para a compreensão: os pesquisadores do presente têm condições de ver as implicações de ordem material e cultural que os contemporâneos da varíola não conseguiam enxergar. É na tensão entre a familiaridade e a diferença que o conhecimento histórico avança.

Nesse sentido, procurou-se, neste artigo, situar a varíola no horizonte histórico de Goiás do século XIX até as três primeiras décadas do século XX. O que se viu foi que o significado da doença para aquela população transcendia os aspectos meramente nosológicos e possibilitou clarear a tensão e a ambiguidade da tentativa de se implantar o aspecto higienista do processo civilizador num lugar considerado isolado e atrasado.

Dessa forma, a quase ausência de varíola em Goiás era considerada pelos presidentes de província um mistério, tendo alguns chegado a explicar o fato recorrendo à providência divina (Goiás, 1850). O relatório do presidente Antero Cícero de Assis é esclarecedor a esse respeito: "A Província é salubre, pois vive isenta de algumas das epidemias que flagelam outras localidades e, mesmo das moléstias endêmicas, nenhuma se apresenta com o caráter aterrador. E isto é de suma felicidade para Província, onde os médicos são raros e os princípios higiênicos não podem ser observados com a necessária pontualidade" (Goiás, 1875, p.27).

A expressão "suma felicidade" foi a única encontrada pelo presidente na avaliação da saúde pública em Goiás, onde, paradoxalmente, não se observavam os preceitos higienistas, mas não se verificavam casos de epidemias graves. De fato, pelo menos no que se refere à varíola, Goiás foi poupado dos surtos epidêmicos que atingiram províncias fronteiriças, como Minas Gerais e Cuiabá. ${ }^{15}$ Quase imobilizados pela ausência de verbas para implementar ações mais 
efetivas por parte do Estado para livrar Goiás do isolamento e do atraso, os administradores não perceberam que era justamente isso que explicava a ausência da varíola. No século XX, o progresso da infraestrutura dos meios de transportes e do crescimento demográfico - o lado material do processo civilizador - veio acompanhado de surtos epidêmicos de varíola em várias localidades goianas.

Apesar da quase ausência de surtos de varíola, os presidentes empenharam-se em promover a vacinação antivariólica em Goiás, interpretada como prática civilizatória, embora sua eficácia nem sempre fosse comprovada empiricamente. ${ }^{16}$ Entraram em choque com a resistência da população que recusava a vacinação por diversos motivos, mas sobretudo porque desconfiava dos discursos higienistas que a insultavam e a conclamavam a adotar práticas europeias. Com o reaparecimento da moléstia por essas paragens, a população teve que reaprender a lidar com a doença. A vacinofobia parece ter diminuído, mas em contrapartida 'os tubos capilares de vacina' se tornaram produto bem mais raro durante a Primeira República do que durante o Império.

A vacina antivariólica inegavelmente foi um importante instrumental científico para a humanidade, e a erradicação da doença é a maior prova disso. É preciso, no entanto, evitar análise triunfalista de sua história, na qual os defensores da vacina são considerados vencedores, "homens clarividentes, progressistas e incompreendidos em sua época" (Lopes, 1996, p.73), e aqueles que a rejeitaram, derrotados, que, por ignorância e preconceito, não conseguiram contribuir para o avanço da história.

É preciso respeitar e ouvir os argumentos dos vencidos. É preciso situar a resistência à vacinação no universo de valores da época. Além do mais, a vitória e receptividade das práticas civilizatórias não costumam ser totais e absolutas. Em Recife, em 1856, os negros interpretaram a epidemia de cólera que os atingia como artimanha dos brancos para acabar com a população negra (Chalhoub, 2004, p.136). No final do século XX, quando o Ministério da Saúde lançou a campanha de vacinação contra a gripe para maiores de 60 anos, muitos idosos - inclusive o avô do autor - recusaram-se a vacinar, temerosos de que a campanha fosse uma espécie de 'solução final' para os deficit da Previdência Social. Os 'civilizados' de hoje provavelmente serão, no mínimo, cínicos com essa atitude desconfiada dos idosos. No entanto, os idosos estão mais próximos do tempo em que o Estado brasileiro, por todos os meios, procurava implantar a civilização nos trópicos. Se eles temem o Estado, a culpa não é deles, mas do Estado. Sua apreensão não é totalmente descabida, como não foram as 'cemiteradas', o Quebra-Quilos, Canudos, a Revolta da Vacina e outras manifestações populares brasileiras. Nessas revoltas, o povo não sabia bem o que queria, mas com certeza sabia o que não queria: a erosão de suas práticas culturais pelo Estado civilizador.

\section{NOTAS}

\footnotetext{
${ }^{1}$ Segundo Farrel (2003, p.55-64) a ideia da erradicação total da varíola partiu de Viktor M. Zhadanov, ministro da Saúde da União Soviética, que propôs em 1958 na Organização Mundial de Saúde um plano global de vacinação. Essa campanha começou em 1966 e terminou em 1977, quando a Somália se declarou livre da varíola.

${ }^{2}$ Os estudiosos divergem quanto à data da chegada da vacina antivariólica no Brasil: 1798 (Pereira, 2002, p.19), 1801 (Carvalho, 1987, p.95) e 1804 (Chalhoub, 2004, p.107) são algumas das datas levantadas.
} 
${ }^{3}$ Todos os relatórios da província de Goiás citados neste artigo estão disponíveis on line no site do Center for Research Libraries, http://www.crl.edu/brazil/provincial/goías.

${ }^{4}$ Essa é a opinião também da pesquisadora Mary C. Karasch (1999, p.25): “Ao contrário das demais capitanias, parece ter havido poucas epidemias expressivas de varíola em Goiás, o que se explica por duas razões: varíola é uma doença que depende da concentração urbana que leva as pessoas a se encontrarem frequentemente, face a face; a capitania era isolada e rural com baixa densidade populacional".

${ }^{5}$ As informações sobre a ocorrência desse eclipse foram consultadas no site The United Kingdom Hidrographic Office (Total..., s.d.)

${ }^{6} \mathrm{O}$ crédito extraordinário de quatro mil contos de réis aberto pelo presidente Antero Cícero de Assis (Goiás, 1874, anexo A6-1) pode ser dimensionado em comparação com as despesas relacionadas à saúde no Hospital de Caridade São Pedro Alcântara, único de Goiás durante todo o século XIX e localizado na capital: o crédito extraordinário foi maior do que toda a despesa de pessoal do Hospital referente a 1873, que foi de 3:227\$363 (três contos, 227 mil e 363 réis). Foi superior também a todo o gasto de alimentação do hospital nesse ano, que somou 3:784\$008 (três contos, 784 mil e oito réis). A despesa total do hospital, em 1873, foi de 14:202\$709 (14 contos, 202 mil e 709 réis), sendo que cerca de seis contos de réis foram destinados ao pagamento de credores.

${ }^{7}$ Quase a metade dessa quantia foi gasta no pagamento dos honorários do médico Laudelino de Almeida, cerca de dois contos de réis pelo período em que ficou responsável pelos serviços sanitários de Campinas: 26 de março a 20 de maio de 1904.

${ }^{8}$ Justificava-se o cuidado com a desinfecção devido ao grande poder de resistência do vírus da varíola: "crostas de lesão abandonadas por mais de um ano à temperatura ambiente conservam a infectividade na poeira dos cômodos habitados por variolosos, e durante longo tempo poderia ser encontrado o vírus" (Gazêta, 2006, p.27).

${ }^{9}$ Ao contrário do que é difundido pela memória coletiva, até a modernização da economia, na década de 1930, o abastecimento alimentar era bem deficiente. Desse modo, qualquer oscilação climática ou distúrbio social acarretava crise alimentar em Goiás.

${ }^{10}$ Conhecido na historiografia goiana como Chacina do Duro, esse conflito consistiu em disputa de poder entre o coronel Abílio Wolney, chefe político local, e o grupo político que controlava o poder do estado. A tragédia culminou com o assassinato de familiares e amigos do coronel, presos em um tronco, pela polícia. O acontecimento inspirou o livro O Tronco (de Bernardo Élis) e o filme homônimo (dirigido por João Batista de Andrade).

${ }^{11}$ Roy Porter (1992, p.304) afirma que, em sociedades tradicionais, o corpo era desvalorizado em relação à mente, sendo considerado degradado e lugar de pecados e desejos. Isso é importante para relativizar as marcas deixadas pela varíola que, muito provavelmente, não possuíam então o significado que possuem atualmente, quando o corpo é concebido como objeto estético por excelência.

${ }^{12}$ Esse tipo de concepção está presente em muitas anedotas populares antigas. Numa delas, um homem faz um pacto com a morte, vivendo em meios a riquezas até o dia predeterminado para sua morte. Quando chegou esse dia, o tal homem raspou a cabeça, trocou suas roupas e mudou-se para outro lugar, numa tentativa de escapar ao pacto feito. De repente, chega a morte num grupo de pessoas procurando o tal homem, que estava presente. Depois de examinar o ambiente, a morte, resignada, exclama: "para não perder viagem, o jeito é levar esse careca mesmo". Moral da história: não se engana a morte.

13 O médico Jerônimo Carvalho Bueno (1979, p.10) descreveu esse método de cura: "para revigorar o status [sexual], a pessoa escarificava a barriga da perna (região poplítea) até produzir uma ferida. Para que ela não se cicatrizasse, além de ser sempre ativada por um pedaço de madeira, colocava-se dentro dessa ferida um grão de chumbo, maior ou menor de acordo com a lesão, a fim de que ficasse sempre 'merejando' os 'humores'. E isso, transformando em fístula, era carinhosamente cultivado, amarrado com um pano, pois via dela as 'mermas' do corpo se escoavam e tornavam o indivíduo forte e sadio." (destaques do original)

${ }^{14}$ Delumeau (1989, p.56) percebeu que, na Europa moderna, o aumento dos impostos provocava revoltas não só pelo encargo, mas também pela novidade, como o advento dos papéis timbrados.

${ }^{15} \mathrm{O}$ presidente Couto de Magalhães em 1863 noticiou o infundado "receio de que a bexiga aparecesse na Província, vinda da cidade Uberaba, onde fez muitas vítimas" (Goiás, 1863, p.67), e o presidente João Bonifácio Gomes, em 1868, mostrou-se aliviado pelo fato de Goiás ser "felizmente preservado do terrível flagelo das bexigas que grassam em Cuiabá, ceifando extraordinário número de vítimas" (Goiás, 1869, p.2) 
${ }^{16} \mathrm{Na}$ abertura da Assembleia Legislativa, em 1o de setembro de 1867, temeroso de a varíola atingir Goiás a partir de Cuiabá, o presidente João Bonifácio G. Siqueira enviou "tubos e lâminas com fluido vacínico, conquanto o comissário vacinador declarasse que pouco ou nenhuma esperança tinha de que ele produza resultado profícuo" (Goiás, 1870, p.4). A distância entre Goiás e o Rio de Janeiro fazia com que a vacina humana perdesse a eficácia, o que explica a descrença do comissário vacinador.

\section{REFERÊNCIAS}

ABREU, Edmundo Pinheiro de.

Curralinho, seus costumes e sua gente. Goiânia: Oriente. 1978.

ALENCASTRE, José Martins Pereira de. Anais da Província de Goiás. Goiânia: Sudeco. 1979.

ALMEIDA, Thomaz Cardoso de; FOGGIA, Vicente Moretti.

Tratamento da Varíola. Correio Oficial de Goyaz, Goiás. 15 maio 1866.

BERTRAN, Paulo.

Formação econômica de Goiás. Goiânia: Oriente. 1978.

BRASIL, Americano do.

Pela história de Goiás. Goiânia: Editora da UFG. 1980.

BUENO, Jerônimo Carvalho.

História da medicina em Goiás. Goiânia: edição do autor. 1979.

CARVALHO, José Murilo de.

Os bestializados: o Rio de Janeiro e a República que não foi. São Paulo: Companhia das Letras. 1987.

CHALHOUB, Sidney.

Cidade febril. São Paulo: Companhia das Letras. 2004.

CARTA...

[Carta ao primo Vicente]. Caixa dos municípios. Campinas. Caixa 01. (Arquivo Histórico Estadual, Goiânia). 17 fev. 1904.

COSTA, Jurandir Freire.

Ordem médica e norma familiar. Rio de Janeiro:

Graal. 1979.

CRÔNICAS...

Crônicas da Comunidade Redentorista de

Campinas de Goiás. (Arquivo dos Padres

Redentoristas, Goiânia). 1926-1939.

CRÔNICAS...

Crônicas dos Padres Redentoristas de Campinas.

Goiânia. (Arquivo dos Padres Redentoristas,

Goiânia). 1903-1907.

DE GOIÁS.

De Goiás. O Planalto, Santa Luzia. 12 out. 1910.
DE GOIÁS.

De Goiás. O Planalto, Santa Luzia. 5 out. 1910.

DELUMEAU, Jean.

História do medo no Ocidente. São Paulo:

Companhia das Letras. 1989.

ELIAS, Norbert.

A solidão dos moribundos. Rio de Janeiro: Jorge Zahar. 2001.

ELIAS, Norbert.

O processo civilizador: uma história dos costumes. Rio de Janeiro: Jorge Zahar. v.1. 1994.

ÉLIS, Bernardo. Joãoboi. In: Teles, Gilberto Mendonça (Sel.). Os melhores contos de Bernardo Élis. São Paulo: Global. p.117-130. 2003.

FARREL, Jeannet.

A assustadora história das epidemias. São Paulo: Ediouro. 2003.

\section{FERNANDES, Tânia Maria.}

Vacina antivariólica: ciência, técnica e o poder dos homens (1808-1920). Rio de Janeiro: Editora Fiocruz. 1999.

FREYRE, Gilberto.

Casa-grande e senzala. Rio de Janeiro: Record. 1996.

GADAMER, Hans-George.

Verdade e método. Petrópolis: Vozes. 1997.

GAZÊTA, Arlene Audi Brasil.

Uma contribuição à história do combate à varíola no Brasil: do controle à erradicação. Tese

(Doutorado) - Casa de Oswaldo Cruz, Fundação Oswaldo Cruz, Rio de Janeiro. 2006.

GEERTZ, Clifford.

O saber local. Tradução Vera Mello Joscelyne. Petrópolis: Vozes. 1997.

GOIÁS.

Mensagem enviada ao Congresso na abertura da Quinta Legislatura pelo presidente do estado José Xavier de Almeida, 1905. Memórias Goianas, Goiânia, 16, p.131-163. 2003.

GOIÁS.

Mensagem apresentada ao Congresso Legislativo do Estado de Goyaz por Urbano Coelho de Gouvea. (Arquivo do Instituto de Pesquisa Histórica Brasil Central, Goiânia) 15 mar. 1911. 
GOIÁS.

Relatório apresentado pelo doutor Laudelino Gomes de Almeida. Caixa dos Municípios. Campinas. Caixa 03. (Arquivo Estadual de Goiás, Goiânia). 1904.

GOIÁs.

Relatorio apresentado pelo illm. e exm. sr. dr. Aristides de Souza Spinola, presidente da provincia a Assemblea L. Provincial de Goyaz, no dia $1^{\circ}$ de março de 1880 . Goyaz: Typographia Provincial. 1880.

\section{GOIÁs.}

Relatorio apresentado a Assemblea Legislativa Provincial de Goyaz pelo Exm. Sr. Dr. Antero Cicero de Assis, presidente da provincia, em 1으․ jun. 1875. Goyaz: Typographia Provincial. 1875.

\section{GOIÁS.}

Relatorio apresentado a Assemblea Legislativa Provincial de Goyaz, pelo Exm. Sr. Dr. Antero Cicero de Assis, presidente da provincia, em $1^{\circ}$ jun. 1874. Goyaz: Typographia Provincial. 1874.

\section{GOIÁS.}

Relatorio que o exm sr. desembargador João Bonifacio Gomes de Siqueira, 1ㅇvㄹice-presidente da provincia de Goyaz, leu na abertura da Assemblea Legislativa da mesma provincia, no dia $1^{\circ}$ de setembro de 1867 . Goyaz: Typographia Provincial. 1870.

\section{GOIÁs.}

Relatorio que o exm. sr. desembargador João Bonifacio Gomes de Siqueira, 1ํ vice-presidente da provincia de Goyaz, leu na abertura da Assemblea Legislativa da mesma provincia no dia 1을 de setembro de 1868. Goyaz: Typographia Provincial. 1869.

\section{GOIÁs.}

Relatorio apresentado à Assembléa Legislativa de Goyaz pelo presidente da provincia, o ex.mo sr. dr. José Vieira Couto de Magalhães, no dia 1을 junho de 1863. Goyaz: Typographia Provincial. 1863.

\section{GOIÁS.}

Relatorio apresentado à Assemblea Legislativa Provincial de Goyaz na sessão ordinária de 1856, pelo Exm. presidente da província, dr. Antônio Augusto Pereira da Cunha. Goyaz: Typographia Goyazense, 1856.

\section{GOIÁS.}

Relatorio que a Assemblea Legislativa Provincial de Goyaz apresentou na sessão ordinária de [1ํㅡㄹ de setembro de] 1855 o exm. presidente da provincia, Antonio Candido da Cruz Machado. Goyaz: Typographia Goyazense. 1855.
GOIÁS.

Relatorio que a Assemblea Legislativa de Goyaz apresentou na sessão ordinária de [1ํำ de junho de] 1853 o exm. presidente da mesma provincia, doutor Francisco Mariani. Goyaz: Typographia Provincial. 1853.

GOIÁs.

Relatorio que a Assemblea Legislativa de Goyaz apresentou na sessão ordinária de [1ำ de junho de] 1852 o exm. presidente da mesma provincia, doutor Antonio Joaquim da Silva Gomes. Goyaz: Typographia Provincial. 1852.

GOIÁS.

Relatorio que a Assemblea Legislativa de Goyaz apresentou na sessão ordinária de [1ํ de maio de] 1851 o exm. presidente da mesma provincia, doutor Antonio Joaquim da Silva Gomes. Goyaz: Typographia Provincial. 1851.

GOIÁs.

Relatorio com que o ex-presidente da provincia de Goiaz, o Sr. Doutor Eduardo Olimpio Machado entregou a presidência da mesma ao seo successor, o Exm. Sr. Doutor Antonio Joaquim da Silva Gomes [em 21 de julho de 1850]. Goiaz: Typographia Provincial. 1850.

GOIÁS.

Relatorio que a Assemblea Assembleia Legislativa de Goyaz apresentou na sessão ordinaria [de $1^{\circ}$ de maio] de 1847 o exm. presidente da mesma provincia, doutor Joaquim Ignacio Ramalho. Goyaz, Typographia Provincial. 1847.

GOIÁs.

Relatorio que a Assemblea Legislativa de Goyaz apresentou na sessão ordinária de $\left[1^{\circ}\right.$ de junho de] 1845 o exm. presidente da mesma provincia, doutor Jose de Assiz Mascarenhas. Goyaz: Typographia Provincial. 1845.

GOIÁs.

Relatorio que a Assemblea Legislativa de Goyaz apresentou na sessão ordinária de [1ํㅡe outubro de] 1840 o exm. presidente da mesma provincia, d. Joze de Assiz Mascarenhas. Goyaz: Typographia Provincial. 1840.

GOIÁs.

Relatorio que a Assemblea Legislativa de Goyaz apresentou na sessão ordinária de [1을 outubro de 1839] o Exm. presidente da mesma província, d. Joze de Assiz Mascarenhas. Goyaz: Typographia Provincial. 1839.

GROSTOM, Florêncio Antônio da Fonseca. Obras poéticas dedicadas e oferecidas ao ilustríssimo Juiz de Órfãos do Julgado de Meia Ponte, Capitão Joaquim Alves de Oliveira por Florêncio Antônio da Fonseca Groston. In: Memórias Goianas 1. Goiânia: Universidade Católica de Goiás. 1982. 
KARASCH, Mary C.

História das doenças e dos cuidados médicos na capitania de Goiás. In: Freitas, Lena Castello Branco de (org.). Saúde e doenças em Goiás: a medicina possível. Goiânia: Editora da UFG, p.19-62. 1999.

LEAL, Oscar.

Viagem às terras goyanas. Goiânia: Editora da UFG. 1980.

LOPES, Myriam B.

O sentido da vacina ou quando o prever é um dever. História, Ciências, Saúde -

Manguinhos, Rio de Janeiro, v.3, n.1, p.65-79. 1996.

OFÍCIO...

Ofício do ministro e secretário de Estado dos Negócios do Império ao presidente Dr. José Pereira Rego, em 24 de outubro de 1870. Correio Oficial de Goyas, Goiás. 28 jan. 1871.

OFÍCIO...

Ofício de João Alves de Castro, secretário do Interior e Justiça e Segurança Pública, de 20 de maio de 1904. Jornal Semanário Oficial de Goiás, Goiás. 11 de jun. 1904.

OFÍCIO...

Ofício de João Alves de Castro, secretário do Interior, Justiça e Segurança Pública, de 20 de fevereiro de 1904. Jornal Semanário Oficial de Goiás, Goiás. 19 mar. 1904.

OLIVEIRA, Adriana Mara Vaz de.

Uma ponte para o mundo goiano do século XIX: um estudo da casa meiapontense. Goiânia: Agepel. 2001.

PALACIN, Luís.

O século do ouro em Goiás. Goiânia: Ed. da UCG. 1994.

PALACIN, Luís; MORAES, Maria Augusta de S. História de Goiás. Goiânia: Ed. da UCG. 2001.

PEREIRA, Leonardo.

As barricadas da saúde: vacina e protesto popular no Rio de Janeiro da Primeira República. São Paulo: Fundação Perseu Abramo. 2002.

PORTER, Roy.

História do corpo. In: Burke, Peter (org.). A escrita da história: novas perspectivas. São Paulo: Editora da Unesp, p.291-327. 1992.
PÓVOA, Osvaldo Rodrigues.

Quinta-feira sangrenta. Dianópolis: edição do autor. 1975.

REBELLO, Péricles Xavier.

Usos e costumes do estado de Goiás (1900-1980). Goiânia: edição do autor. 1987.

REIS, José Carlos.

O cotidiano da morte no Brasil oitocentista. In: Alencastro, Luiz Filipe (org.). História da vida privada no Brasil (2): império: a corte e a modernidade nacional. São Paulo: Companhia das Letras, p.96-143. 1997.

REVEL, Jacques; PETER, Jean-Pierre.

O corpo: o homem doente e sua história. In: Le Goff, Jacques; Nora, Pierre. História: novos objetos. Rio de Janeiro: Francisco Alves, p.141159. 1976.

SEVCENKO, Nicolau.

A Revolta da Vacina: mentes insanas em corpos rebeldes. São Paulo: Brasiliense. 1984.

SILVA, Ana Lúcia da.

A Revolução de 30 em Goiás. Goiânia: Cânone; Agepel. 2001.

SONTAG, Susan.

A doença como metáfora. Rio de Janeiro: Graal. 2002.

TEIXEIRA, Luís Antônio.

“Alastrin, varíola é?". História, Ciências, Saúde

- Manguinhos, Rio de Janeiro, v.7, n.1, p.49-72. 2000.

TEIXEIRA, Luis Antônio; ALMEIDA, Maria de. Os primórdios da vacina antivariólica em São Paulo: uma história pouco conhecida. História, Ciências, Saúde - Manguinhos, Rio de Janeiro, v.10, supl.2, p.475-98. 2003.

TOTAL...

Total eclipse of the Sun: 1811 March 24. The United Kingdom Hidrographic Office. 20062011. Disponível em: http://astro.ukho.gov.uk/ eclipse/0211811/. Acesso em 7 abr. 2012. s.d.

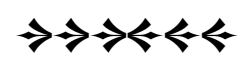

